INTERNATIONAL ELECTRONIC JOURNAL OF MATHEMATICS EDUCATION
IENME

\title{
Mathematics really generates anxiety? Empirical Study in middle school students
}

\author{
Arturo Córdova-Rangel ${ }^{a}$ \\ Milka E. Escalera-Chavez ${ }^{\text {b }}$ \\ Samanta Briones Gascac
}

\begin{abstract}
aUniversidad Politécnica de Aguascalientes, México b y cUniversidad Autónoma de San Luis Potosí, México
\end{abstract}

\begin{abstract}
The goal of this study was to identify the anxiety factors perceived by students toward mathematics and determine if they are gender related. The study is of quantitative and transversal type. The sample was comprised of 155 students belonging to two middle schools from the Cárdenas municipality in San Luis Potosí and a non-probabilistic sampling was used. The 12 question instrument corresponds to the anxiety construct from the Fennema \& Sherman scale. An ANOVA analysis and an exploratory factor analysis were applied to the data obtained. The results show that students present a high level of anxiety, furthermore, they also show there is no significant difference between men and women to anxiety toward mathematics and the anxiety factors perceived as the cause of said anxiety are insecurity and lack of self-confidence. And finally, it is concluded that middle school level students perceive a significant level of anxiety regardless of gender. They also manifest a feeling of nervousness and confusion toward the discipline and would not find it in the least agreeable to take even more math courses.
\end{abstract}

KEYWORDS

Mathematics anxiety, confidence in mathematics and gender related anxiety toward mathematics.
ARTICLE HISTORY

Received 29 September 2016 Revised 21 October 2016 Accepted 01 November 2016 


\section{Introduction}

Mathematics are necessary in all aspects of life, not because of the fact of being implicitly part of most any career curriculum, or by seemingly being a competence acquired during school formation and exclusively applied to that environment, but rather because they are a part of everyday life (Caballero and Blanco, 2007; Pérez, Castro, Segovia, Castro, Fernández and Cano, 2009; PISA, 2012). Much in the same way, international organizations such as PISA (Program for International Student Assessment) stated in 2012 that mathematics is a key area for an individual's development, being that not only is mathematics used in a school or professional field, it is also applied to situations faced in a real life environment.

Unfortunately, in Mexico students present deficiencies, only 4\% of students are able to solve complex mathematic problems and develop abstract thought, as stated by the test result of PISA (2012). On the other hand, results from the evaluation PLANEA (2015) which is applied by SEP show that students have a low performance since $65.4 \%$ of them can only solve basic operations, in this regard the National Institute for Evaluation of Education (INEE [Instituto Nacional para la Evaluación de la Educación], 2015) mentions that having students acquire key knowledge has not yet been achieved, nor have been the essential lessons detailed in the study plan.

One of the causes for this low performance as stated by PISA (2012) is the anxiety this field of science produces in students; therefore, we must ask ourselves, is anxiety toward mathematics a new term? And this term, how is it defined? Regarding the first question one can easily overlook that since 1957, Dreger and Aiken first introduced the term "anxiety toward mathematics" as a way of describing the difficulties and attitude of students with mathematics. In spite of the difficulty to define and measure mathematics anxiety (Wood, 1988), several evaluation attempts have been made.

Dreger and Aiken developed one of the first questionnaires, called the Number Anxiety Scale, in 1957. Afterwards, more comprehensive scales such as the Mathematics Anxiety Rating Scale (Richardson \& Suinn,1972), the FennemaSherman Mathematics Attitudes Scales (Fennema \& Sherman, 1976), the Anxiety Towards Mathematics Scale (Sandman,1980), and the Mathematics Anxiety Questionnaire (Wigfield \& Meece,1988) were developed. Even when the Mathematics Anxiety Rating Scale (MARS; Richardson \& Suinn, 1972) is one of the most extensively used mathematics anxiety questionnaires, Alexander and Martray (1989) identified two important shortcomings. The first is that it is a long assessment instrument (98 items), which is time-consuming to answer. However, the Revised Mathematics Anxiety Rating Scale (RMARS; Alexander \& Martray), developed from the original MARS, has only 25 items. The ideas presented above show that in fact, the word "anxiety towards mathematics" is not new, already since then had it been conceptualized.

Wood (1988) cited by Pérez et al. (2009) states that mathematic anxiety is characterized by the lack of comfort one might experience when pressured to perform in mathematics. Contrary to this, Fennema and Sherman cited too by Pérez et al. (2009), consider that mathematic anxiety consists in a series of feelings of anguish, terror, nervousness and physical symptoms that arise when 
solving problems related to mathematics. Students consider mathematics to be one of the most difficult subjects, precisely this perception is generating prejudice and predispositions toward this discipline, thus, a negative attitude is conducive to a high anxiety state that blocks learning (Stubblefield, 2006, cited by Kargar, Tarmizi, Bayat, 2010, Aliasgar, Riahini, Mojdehavar, 2010).

Richardson and Suinn (1972) on the other hand state that anguish in a student causes their mathematical reasoning to diminish, and performance and attitudes to transform. Pérez et. al. (2009), as well as Kazleskis (2000) cited by Mato-Vázquez and Muñoz-Cantero (2010) have proven that a concerned student anguishes before and after exams, and gets nervous when put to solve problems when there is a time limit involved.

Some authors (Fennema \& Sherman, 1976, Wigfield \& Meece, 1988, Hembree, 1999, Ursini, 2013) consider anxiety in men and women to be different. Fennema and Sherman (1976) consider that female students are more anxious than male students. Wigfield and Meece (1988) meanwhile, present evidence that suggests that adolescent females manifest more nervousness, stress and discomfort than adolescent males and Hambree (1999) exhibits women as being affected more by anxiety toward mathematics. While Ursini (2013) presents evidence that female students from middle school in the state of Mexico present higher levels of anxiety than their male counterparts.

Passolunghi, Caviola, Agostini, Perin and Mammarella (2016), describe too the subject about the mathematics anxiety and its relation with the working memory and the mathematics performance in secondary-school children. And their summary of the research is: 
"Mathematics anxiety (MA) has been defined as "a feeling of tension and anxiety that interferes with the manipulation of numbers and the solving of math problems in a wide variety of ordinary life and academic situations". Previous studies have suggested that a notable proportion of children in primary and secondary school suffer from MA, which is negatively correlated with calculation skills. The processing efficiency and attentional control theories suggest that working memory (WM) also plays an important part in such anxious feelings. The present study aimed to analyze the academic achievement and cognitive profiles of students with high math anxiety (HMA) and low math anxiety (LMA). Specifically, 32 students with HMA and 34 with LMA matched for age, gender, generalized anxiety, and vocabulary attending sixth to eighth grades were selected from a larger sample. The two groups were tested on reading decoding, reading comprehension, mathematics achievement, and on verbal short-term memory and WM. Our findings showed that HMA students were weak in several measures of mathematics achievement, but not in reading and writing skills, and that students with HMA reported lower scores on short-term memory and WM performances (with associated difficulties in inhibiting irrelevant information) than children with LMA. In addition, a logistic regression showed that weaknesses in inhibitory control and fact retrieval were the strongest variables for classifying children as having HMA or LMA".

Kotecha M. (2016) comments too, about the reducing anxiety in the mathematics and statistics. And contribute with some questionnaires and case studies in practice.

In line with these arguments, it is reasonable to assume that the anxiety phenomenon in women toward mathematics, which has been proven in some studies, is probably a personality trait in women because of their own nature to try to be perfectionists, which could probably cause certain difficulty in their learning experience. Remembering what Dreger and Aiken (1957) referred to anxiety as a term to describe the attitude and difficulty of a student toward the mathematics subject. In this regard, they defined it as "the presence of an emotional reaction syndrome toward arithmetic and mathematics" (p. 344). In spite of the difficulty to define and measure mathematics anxiety (Wood, 1988), several evaluation attempts have been made.

With the aforementioned concepts and observations made, come forth the following research questions: Do middle school students present anxiety toward mathematics? Is there a group of factors that students perceive which cause anxiety toward mathematics? Are there any gender related differences to anxiety toward mathematics?

For that reason, the objective of this research is to determine whether middle school students have anxiety problems toward mathematics, and also show what factors students identify as causing their anxiety. And at the same time prove if there is a significant difference in the level of anxiety between men and women. To guide and lead this study, the following hypothesis were formulated: 
H1: Middle school students have anxiety toward mathematics.

$\mathrm{H} 2$ : There is a gender related difference to anxiety in middle school students.

H3: There is a group of factors perceived by the students which cause anxiety.

The importance of this research lies in that the results will provide relevant information, so that authorities in education at this level can develop strategies and procedures to aid students that so require it, be them men or women, because anxiety presents itself regardless of gender. This would all contribute in the effort to improve academic achievement.

\section{METHODOLOGY}

The study is approached from a quantitative focus, non-experimental, taking into consideration that the $\mathrm{X}$ variables that could modify $\mathrm{Y}$ are not manipulated, also of a cross-sectional nature being that the gathering of data is only done once during a specified time. The study is of exploratory type and group mean differences because the focus of this research is to analyze the factors that contribute to or generate anxiety levels toward mathematics. Likewise, the aim is to identify the difference and statistical significance between gender and anxiety toward mathematics (Hair, 1999). For this study in particular the sample is non-probabilistic because the element selection does not depend on probability, but in the causes related to the research characteristics (Hernández, Fernández \& Baptista, 2010).

The sample was randomly selected and it included 155 students from two middle schools in the Cárdenas municipality of San Luis Potosí; the sample was integrated by 75 men and 80 women. The data was collected by an instrument consisting in 12 questions, which correspond to the anxiety construct from the Fennema and Sherman scale. The internal consistency test Cronbach's alpha resulted in 0.874 which according to theory is acceptable. An exploratory factor analysis and a variance analysis (ANOVA) were used as statistical techniques; and for data processing SPSS v23 software was used.

\section{RESEARCH RESULTS}

This section details the results of the statistic tests. Table 1 shows the descriptive statistics for the variables: gender, school and age. In the gender variable we can observe that $55.5 \%$ belong to middle school 1 and $44.5 \%$ belong to middle school 2, additionally, we can see there are more women $(51.6 \%)$ than men taking math class, even though there are more men in school $1(30.3 \%)$ than women (25.2\%). The age of students ranges from 14 to 16 .

Table 1. Descriptive variables

\begin{tabular}{lccc}
\hline \multicolumn{1}{c}{ Gender } & Middle school 1 & $\begin{array}{c}\text { Middle school } \\
2\end{array}$ & Total \\
\hline Male & $30.3 \%$ & $18.1 \%$ & $48.4 \%$ \\
\hline Female & $25.2 \%$ & $26.5 \%$ & $51.6 \%$ \\
\hline Total & 55.5 & 44.6 & 100 \\
\hline
\end{tabular}




\begin{tabular}{cccc}
\hline Age & Middle school 1 & Middle school & Total \\
& & 2 & \\
\hline 14 & $12.9 \%$ & $11.0 \%$ & $23.9 \%$ \\
\hline 15 & $39.4 \%$ & $32.9 \%$ & $72.3 \%$ \\
\hline 16 & $3.2 \%$ & $0.6 \%$ & $3.9 \%$ \\
\hline Total & $55.5 \%$ & 55.5 & $100.0 \%$ \\
\hline$\%$ of students & 55.5 & 44.5 & 100.0 \\
\hline Source: Self made & & &
\end{tabular}

Regarding the null hypothesis $\mathrm{H} 0$ that states: Middle school students have anxiety problems toward mathematics, table 2 shows the results and states that the value of "t" is -0.763 for a significance level of 0.05 .

Table 2. Anxiety toward mathematics calculation

\begin{tabular}{cccccc}
\hline $\mathrm{N}$ & $\bar{X}_{\text {Cal }}$ & $\sigma$ & $\bar{X}_{\text {Theoretic }}$ & $\mathrm{t}$ & Sig. \\
& 31.4839 & 8.41871 & 32.0 & -0.763 & 0.446 \\
\hline 155 & Source: Self-made & & & &
\end{tabular}

Using the value $t$ to prove the hypothesis, a calculated $t$ value $(t=-0.763)$ was obtained, said value is less than the critical value ( $\mathrm{t}=1.645$; df 154), which indicates there is enough evidence to state that middle school students have anxiety problems in this field of study.

In relation to gender, results show there is no difference between men and women related to math anxiety, because the calculated Fcalculated (0.427) is less than the value of Ccritical (3.92), furthermore the significance value (0.514) is higher than 0.5 , which gives evidence to prove that both men and women suffer anxiety toward this field.

Table 3. ANOVA

\begin{tabular}{|l|c|c|c|}
\hline & $\mathrm{df}$ & $\mathrm{F}$ & Significance \\
\hline Between groups & 1 & .427 & .514 \\
\hline Inside groups & 153 & & \\
\hline Total & 154 & & \\
\hline \multicolumn{4}{|c|}{ Source: Self made }
\end{tabular}

In terms of Ho2, there is a group of elements that explain math anxiety in students from middle school. Table 1 states firstly the correlation between the variables to prove if the correlation matrix is significant. Table 4 and 5 show that the values for the Kaiser-Meyer-Olkin (KMO) test and the Bartlett sphericity test are greater than 0.50 , as well as the Measure of Sample Adequacy (MSA) (table 5). Besides, the values show that the correlation matrix is significant (table 4).

Table 4. Correlation matrix

\begin{tabular}{cllllllllllll}
\hline Correlation & \multirow{2}{*}{ X11 } & $\mathrm{X} 12$ & $\mathrm{X} 13$ & $\mathrm{X} 14$ & $\mathrm{X} 15$ & $\mathrm{X} 16$ & $\mathrm{X} 17$ & $\mathrm{X} 18$ & $\mathrm{X} 19$ & $\mathrm{X} 20$ & $\mathrm{X} 21$ & $\mathrm{X} 22$ \\
\hline $\mathrm{X} 11$ & 1.000 & 0.644 & 0.454 & 0.488 & 0.491 & 0.532 & 0.460 & 0.155 & 0.316 & 0.421 & 0.410 & 0.425 \\
$\mathrm{X} 12$ & & 1.000 & 0.436 & 0.450 & 0.480 & 0.512 & 0.423 & 0.255 & 0.351 & 0.440 & 0.381 & 0.448 \\
$\mathrm{X} 13$ & & & 1.000 & 0.424 & 0.417 & 0.468 & 0.140 & 0.165 & 0.214 & 0.418 & 0.326 & 0.355
\end{tabular}




\begin{tabular}{|c|c|c|c|c|c|c|c|c|c|}
\hline $\mathrm{X} 14$ & 1.000 & 0.486 & 0.522 & 0.402 & 0.227 & 0.265 & 0.258 & 0.259 & 0.293 \\
\hline $\mathrm{X} 15$ & & 1.000 & 0.597 & 0.411 & 0.268 & 0.357 & 0.401 & 0.409 & 0.292 \\
\hline $\mathrm{X} 16$ & & & 1.000 & 0.326 & 0.215 & 0.345 & 0.266 & 0.304 & 0.373 \\
\hline $\mathrm{X} 17$ & & & & 1.000 & 0.354 & 0.392 & 0.444 & 0.364 & 0.323 \\
\hline $\mathrm{X} 18$ & & & & & 1.000 & 0.141 & 0.192 & 0.224 & 0.439 \\
\hline X19 & & & & & & 1.000 & 0.298 & 0.264 & 0.282 \\
\hline $\mathrm{X} 20$ & & & & & & & 1.000 & 0.518 & 0.401 \\
\hline $\mathrm{X} 21$ & & & & & & & & 1.000 & 0.328 \\
\hline $\mathrm{X} 22$ & & & & & & & & & 1.000 \\
\hline
\end{tabular}

Table 5. Statistic Tests

\begin{tabular}{|l|c|}
\hline Kaiser-Meyer-Olkin (KMO) test & 0.872 \\
\hline Bartlett Sphericity test - Approx. Chi-square df (66) & 678.994 \\
\hline Significance & 0.000 \\
\hline Measure of Sample Adequacy (MSA): \\
$\mathrm{X}_{5}=.814 ; \mathrm{X}_{6}=.714 ; \mathrm{X}_{7}=.915 ; \mathrm{X}_{8}=.829 ; \mathrm{X}_{9}=.913 ; \mathrm{X}_{10}=.853 ; \mathrm{X}_{11}=$ \\
$.886 ; \mathrm{X}_{12}=.924 ; \mathrm{X}_{13}=.853 ; \mathrm{X}_{14}=.909 ; \mathrm{X}_{1} 5=.900 ; \mathrm{X}_{16}=.884$. \\
\hline \multicolumn{2}{|c}{ Source: Self made }
\end{tabular}

Table 6 shows that there are two elements the variables concentrate into, for the first element the variables with the higher value are $\mathrm{X}_{16}$ (0.7989) and $\mathrm{X}_{11}(0.721)$ which contribute to a variance of $64.9 \%$ and $62.8 \%$ respectively, for the element that follows the variables with a higher value are $\mathrm{X}_{17}(0.723)$ and $\mathrm{X}_{18}(0.680)$, with a variance of $52.4 \%$ and $53.8 \%$.

Also, table 6 shows the total variance (52.03\%) which is higher than $50 \%$ indicating that both factors together have a very acceptable applied significance (table 6).

Table 6. Element matrix, communalities, eigenvalue and variance

\begin{tabular}{|c|c|c|c|}
\hline \multirow[t]{2}{*}{ Variables } & \multicolumn{2}{|c|}{ Component } & \multirow[t]{2}{*}{ Communalities } \\
\hline & 1 & 2 & \\
\hline $\mathrm{X}_{16}$ & .789 & & .649 \\
\hline $\mathrm{X}_{11}$ & .721 & & .628 \\
\hline $\mathrm{X}_{14}$ & .708 & & .532 \\
\hline $\mathrm{X}_{13}$ & .700 & & .506 \\
\hline $\mathrm{X}_{15}$ & .687 & & .572 \\
\hline $\mathrm{X}_{12}$ & .653 & & .594 \\
\hline $\mathrm{X}_{18}$ & & .723 & .524 \\
\hline $\mathrm{X}_{17}$ & & .680 & .538 \\
\hline $\mathrm{X}_{22}$ & & .656 & .505 \\
\hline $\mathrm{X}_{20}$ & & .602 & .484 \\
\hline $\mathrm{X}_{21}$ & & .560 & .424 \\
\hline Eigen value & 5.11 & 1.133 & \\
\hline$\%$ variance & 42.594 & 9.438 & \\
\hline$\%$ variance total & \multicolumn{2}{|c|}{52.033} & \\
\hline \multicolumn{2}{|c|}{$\begin{array}{l}\mathrm{X}_{1} 1=\text { Mathematics doesn't scare } \\
\text { me at all. X12=It wouldn't } \\
\text { bother me at all to take more }\end{array}$} & \multicolumn{2}{|c|}{$\begin{array}{l}\mathrm{X}_{17}=\text { Mathematics makes me feel } \\
\text { uneasy and confused. } \\
\mathrm{X}_{18}=\mathrm{I} \text { have usually been at ease in }\end{array}$} \\
\hline
\end{tabular}




\begin{tabular}{l|ll}
\hline mathematics courses. & mathematics courses. \\
$\mathrm{X}_{13}=$ Usually don't worry about & $\mathrm{X}_{19}=$ Mathematics makes me feel \\
my ability to solve mathematics & uncomfortable and nervous. \\
problems. & $\mathrm{X}_{20}=$ Mathematics makes me feel \\
$\mathrm{X}_{1} 4=\mathrm{I}$ almost never get uptight & uncomfortable, restless, irritable, and \\
while taking mathematics tests. & impatient, \\
$\mathrm{X}_{15}=\mathrm{I}$ have usually been at ease & $\mathrm{X}_{21}=\mathrm{I}$ get a sinking feeling when I \\
during mathematics tests, to & think of trying hard mathematics \\
think clearly when working & problems. \\
mathematics. & $\mathrm{X}_{22}=\mathrm{My}$ mind goes blank and I am \\
$\mathrm{X}_{16}=\mathrm{A}$ mathematics test would & unable. \\
scare me. &
\end{tabular}

\section{CONCLUSIONS}

The results obtained in this research contribute information that allows to say there is in fact anxiety toward mathematics, even more so, that there are certain factors that contribute to math anxiety. Besides, it also allows to prove that there is no difference between men and women regarding this field of study, which means the objective stated for this study was achieved.

The evidence matches the findings presented by Pérez, Castro, Segovia, et al. (2009) who proved that anxiety is an affecting factor in students, especially in evaluation situations or particularly difficult assignments for them, such as mathematics can be.

On the other hand, these results differ from the proposed by Hembree (1990), who assures that the phenomenon of math anxiety affects women more than it does men, in this case being proven there is no difference.

But, what could the practical implications of these findings be? And that could be the starting point for the proposal of didactic strategies that are feasibly incorporated in Mexico's education system. For that we can point out that these strategies should be driven to the production of didactic methods that would allow to work closer with students, with the goal of contributing to the reduction of factors that cause math anxiety in students.

Furthermore, the aforementioned didactic strategies should provide indicators that help understand specific behaviors that are affecting the teaching-learning process of math subjects in all levels of study.

The math anxiety phenomenon is not exclusive to under-achieving students or schools, there are even students who have had a very good academic performance be it from elementary, middle school, high school and superior education levels who, even then, have been notably affected by the negativity sentiment or apparent rejection toward math. Which results in an anxiety behavior towards this discipline. From there derives the importance of teachers' actions both within and outside the classroom, because it is advisable for teachers to channel this actions to the correction and prevention of situations associated to anxiety generating elements. 
Understanding those anxiety generating factors is a fundamental function of a teacher. This understanding will allow the teacher to modify his teachinglearning strategy as needed. This can probably be modified to accommodate emotional or academic counseling for those students for whom math problems generate a high level of anxiety. The math problems or assignment contextualization itself can be an attitude change trigger, because the student would find it more helpful for himself, than if mathematics is solely conducted in an abstract manner.

It is important to emphasize that when we talk of math, we mean the general field of this unbending discipline. Remembering that in education, there are other areas of mathematics such as statistics, arithmetic, geometry, differential and integral calculus, algebra, econometrics among other sub disciplines.

These finding are important due that, since the theory and practice is relevant that before and during, of any course with relation with the mathematics is necessary consider this nervousness and confusion toward the discipline and take action to avoid these situation that can affect the development of the students.

With these results, the academic institution can have more arguments to prepare better the mathematics teachers, before and during any course with relation to the math, to can improve the student learning.

\section{BIBLIOGRAPHY}

Alexander, L., \& Martray, C. (1989) The development of an abbreviated version of the Mathematics Anxiety Rating Scale. Measurement and Evaluation in Counseling and Development, 22, 143150

Caballero, A., Blanco, I. y Guerrero, E. (2007) Las actitudes y emociones ante las matemáticas de los estudiantes para Maestros de la Facultad de Educación de la Universidad de Extremadura. XI SEIEM, 2-14.

Dreger, R. \& Aiken, L. R (1957) The identification of number anxiety in collage population. Journal of Education Psychology, 48, 344-351.

Fennema, E. (1989) The study of affect and mathematics: A proposed generic model for research. In D.B. McLeod \& V.M. Adams (Eds.), Affect and mathematical problem solving: A new perspective (pp. 205-219). New York: Springer Verlag.

Flores, G. y Díaz, M. (2013) México en PISA 2012. Instituto Nacional para la Evaluación de la Educación. Informe, 7-126.

Kotecha, M. (2016) Reducing mathematics and statistics anxiety: questionnaires and case studies in practice. In: SAGE Research Methods Cases. SAGE Publications, Ltd., London, UK. ISBN 9781446273050 DOI: 10.4135/978144627305015595376

Lim, S. y Chapman, E. (2013) An Investigation of the Fennema-Sherman Mathematics Anxiety Subscale. Sage Publications Inc. 26-37.

Martínez, N. y Nortes, A. (2013) ¿Tienen ansiedad hacia las matemáticas los futuros matemáticos? Revista de currículum y formación del profesorado, 153-170. 
Mato, M. D., Muñoz, J. M. (2008) Análisis de las actitudes respecto a las matemáticas en alumnos de ESO. Revista de Investigación Educativa, 26(1) 209-226. Retrieved from: http://www.redalyc.org/articulo.oa?id=283321884011

Mato, M. D. y Muñoz, J. M. (2010) Efectos generales de las variables actitud y ansiedad sobre el rendimiento en matemáticas en alumnos de educación secundaria obligatoria. Ciencias psicológicas, 2010, 4(1).

Passolunghi, M. C., Caviola, S., De Agostini, R., Perin, Ch. and Mammarella, I.C. (2016) Mathematics Anxiety, Working Memory, and Mathematics Performance in Secondary-School Children. Frontiers in Psychology, v.7; 2016, Published online 2016 Feb 2., doi: 10.3389/fpsyg.2016.00042

Palacios, A., Arias, V., y Arias, B. (2014) Las actitudes hacia las matemáticas: construcción y validación de un instrumento para su medida. Revista de Psicodidáctica, 67-91.

Pérez P., Castro E., Segovia I., Castro E., Fernández F. y Cano F. (2009) El papel de la ansiedad matemática en el paso de la educación secundaria a la educación universitaria. PNA, 23-35.

Richardson, F. C, \& Suinn, R. M. (1972) The Mathematics Anxiety Rating Scale. Journal of Counseling Psychology, 19,551-554.

Sandman, R. S. (1980) The mathematics attitude inventory: Instrument and user's manual. Journal for Research in Mathematics Education, 11, 148-149.

Secretaría de Educación Pública (SEP) (2014) Enlace 2013, Resultados Históricos Nacionales 20062013. 3ro, 4to, 5to y 6to de Primaria 1ro, 2do y 3ro de Secundaria. Retrieved from: http://www.enlace.sep.gob.mx/content/gr/docs/2013/historico/24_EB_2013.pdf

Wigfiel D. A., \& Meece, J. L. (1988) Math anxiety in elementary and secondary school students. Journal of Educational Psychology, 80, 210-216. 